\title{
Melting of ice shelves and the mass balance of Antarctica
}

\author{
S. S. Jacobs, H. H. Helmer, \\ Lamont-Doherty Geological Observatory of Columbia University, Palisades, New York 10964, U.S.A. \\ C. S. M. Doake, A. Jenkins and R. M. Frolich \\ British Antarctic Survey, Natural Environment Research Council, Cambridge CB3 OET, England
}

\begin{abstract}
We calculate the present ice budget for Antarctica from measurements of accumulation minus iceberg calving, run-off and in situ melting beneath the floating ice shelves. The resulting negative mass balance of $469 \mathrm{Gt} \mathrm{year}^{-1}$ differs substantially from other recent estimates but some components are subject to high temporal variability and budget uncertainties of $20-50 \%$. Annual accumulation from an earlier review is adjusted to include the Antarctic Peninsula for a total of $2144 \mathrm{Gtyear}^{-1}$. An iceberg production rate of $2016 \mathrm{Gtyear}^{-1}$ is obtained from the volume of large icebergs calculated from satellite images since 1978, and from the results of an international iceberg census project. Ice-shelf melting of $544 \mathrm{Gtyear}^{-1}$ is derived from physical and geochemical observations of meltwater outflow, glaciological field studies and modeling of the sub-ice ocean circulation. The highest melt rates occur near ice fronts and deep within sub-ice cavities. Run-off from the ice-sheet surface and from beneath the grounded ice is taken to be $53 \mathrm{Gtyear}^{-1}$. Less than half of the negative mass balance need come from the grounded ice to account for the unattributed $0.45 \mathrm{mmyear}^{-1}$ in the IPCC "best estimate" of the recent global sea-level rise.
\end{abstract}

\section{INTRODUCTION}

More than $87 \%$ of the Earth's fresh water presently exists in a frozen state and more than $90 \%$ of that ice lies on Antarctica (Meier, 1983). Nourished by evaporative moisture from the Southern Ocean, the Antarctic ice sheet exceeds $29 \times 10^{6} \mathrm{~km}^{3}$ in volume (Drewry and others, 1982) and spreads slowly seaward under the influence of gravity. It begins to float at grounding lines where the ice thins to hydrostatic equilibrium with the surrounding ocean. Subsequent melting and calving of the floating ice has apparently maintained a rough balance between accumulation and attrition over recent decades, and perhaps for the past several millennia (Markov and others, 1968; Barkov, 1971; Zakharov, 1988; Payne and others, 1989). Recent interest in global change has focused attention upon the potential of polar ice sheets to grow or shrink in the near future, thereby altering global sea level (Allison, 1981; Polar Research Board, 1985) However, large uncertainties about the rates of surface accumulation, iceberg calving and in situ melting make it difficult to determine the present-day mass balance. In addition, ice sheets are slow to respond to changes in forcing, and future temperatures and precipitation cannot be accurately predicted.

Iceberg calving and in situ melting and freezing processes have a strong bearing on the dynamics of floating ice shelves, which in turn influence the positions of the grounding lines and the rate that ice flows off the continent (Hughes, 1973). More than $80 \%$ of the total ice-shelf area is in West Antarctica, which has much of its land ice grounded below sea level (Drewry and others, 1982). Calving and basal melting, if not balanced by ice advection, decrease the dimensions of an ice shelf and its ability to retard the seaward motion of land ice. Freezing may increase the area of an ice shelf in contact with bay walls or submarine rises, slowing its advance. With an important role in ice-sheet dynamics and relatively high surface accumulation ( $25 \%$ of net ice-sheet precipitation on $11 \%$ of its area), the ice shelves must be included in any assessment of the overall mass budget. Here, we evaluate Antarctic iceberg production and ice-shelf melting from a variety of observations, and from modeled simulations of the sub-ice shelf ocean circulation. In combination with reported surface accumulations, this information reveals a negative ice budget over the past decade. A significant part of the imbalance comes from our finding of high basal melting of the ice shelves.

\section{BASAL MELTING}

It has been appreciated for some time that melting in the sub-ice shelf cavities could be on the order of tens of $\mathrm{cm}_{\text {year }}{ }^{-1}$, given the pressure dependence of the sea-water freezing temperature and observed ocean-heat transport 


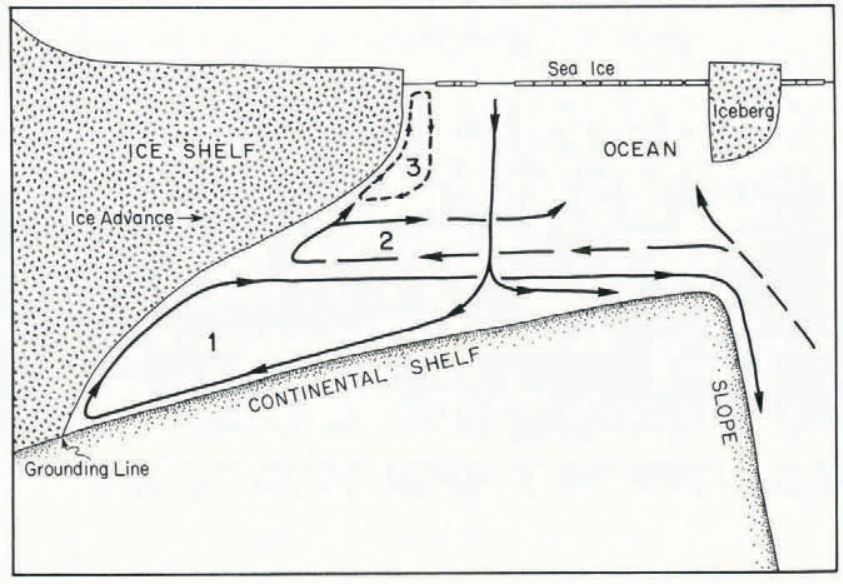

Fig. 1. Schematic diagram of ocean circulation in a vertical plane above the wide Antarctic continental shelf. In the Ross Sea, deep vertical convection is concentrated along the western and southern coastlines and may not penetrate through the more centrally located inflows and outflows. Vertical scale exaggeration $\sim 1000 / 1$. Numbers refer to ice-shelf basal melting modes discussed in the text.

beneath the ice (Wexler, 1960; Crary 1961; Thomas and Coslett, 1970; Doake, 1976; Jacobs and others, 1979). Energy for vertical mixing under the ice, essential for bringing heat into the near-freezing boundary layer, can be derived from the tidal and thermohaline circulations (MacAyeal, 1984a, 1985). Three modes of sub-ice-shelf melting appear to be directly related to the ocean circulation (Fig. 1). In the first and largest volume mode, melting concentrated in the deepest part of the large cavities initiates thermohaline convection in which dense shelf water evolves into very cold but relatively fresh Ice Shelf Water (ISW). This circulation mode is believed to be responsible for both melting and freezing processes beneath major parts of the Filchner-Ronne, Ross and Amery Ice Shelves. The second circulation is linked to intermediate-depth "warm" inflows from the slope-front region. This mode ranges between two extremes, with greater melting where the warmer water fills most of the sub-ice cavity (Potter and Paren, 1985). At the other limit, the inflows are restricted in area or have much of their heat recirculated to the open sea (Jacobs, 1991). The third mode is associated with the relatively shallow bases and walls within $100 \mathrm{~km}$ of the ice fronts, where melting is high due to tidal pumping and the seasonally warmer waters of the coastal current (Jacobs and others, 1985).

The first mode of melting begins with the formation of high-salinity shelf water as the sea surface freezes during winter. The continental shelf typically deepens toward the grounding line (Fig. 1), and this dense shelf water drains beneath the ice shelves. There, its 1 atmosphere freezing temperature can exceed the in situ melting point by as much as $1^{\circ} \mathrm{C}$ due to the $7.5 \times 10^{-4}{ }^{\circ} \mathrm{C} \mathrm{dbar}^{-1}$ decrease in sea-water freezing temperature with increasing depth (Fujino and others, 1974). The latent heat of melting and the heat sink provided by the cold, thick ice shelves give rise to plumes of ISW with temperatures below the sea-surface freezing point (Jacobs and others,

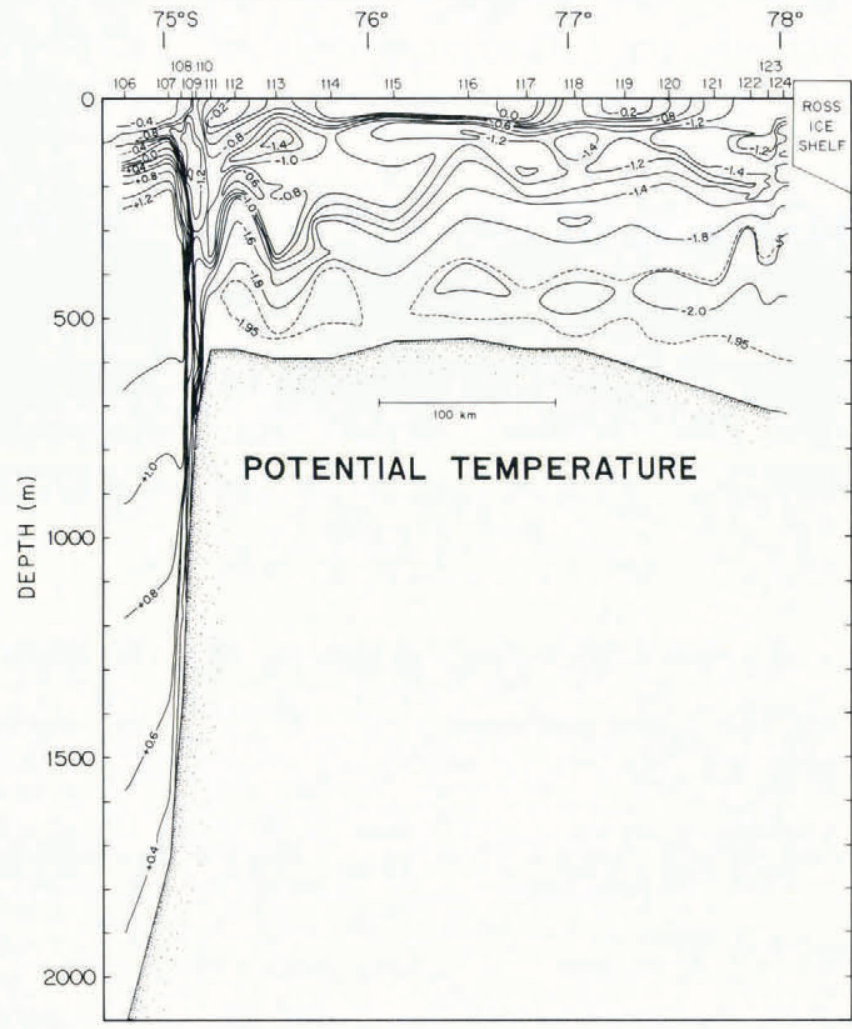

Fig. 2. Ice Shelf Water (ISW) with in situ temperatures colder than the sea-surface freezing point $\left(\sim-1.9^{\circ} \mathrm{C}\right)$ extends at depths of 350-550 $\mathrm{m}$ from beneath the Ross Ice Shelf northward across the central Ross Sea continental shelf and slope. These February 1984 ocean stations were aligned between \#106 at $74.833^{\circ} \mathrm{S}, 175.545^{\circ} \mathrm{W}$ and \#124 at $78.003^{\circ} \mathrm{S}, 179.805^{\circ} \mathrm{W}$ near the ice-shelf front. The ISW results from $86 \mathrm{~km}^{3}$ year ${ }^{-1}$ of the ice-shelf base melting into dense sea water that drains into the sub-ice cavity. Such outflows are known to contribute to Antarctic Bottom Water formation in the Weddell Sea (Foldvik and others, 1985; Jacobs and others, 1985).

1979, 1985; Foldvik and others, 1985; MacAyeal, 1985; Fig. 2). Geochemical tracers have been used to document the presence of glacial ice meltwater in the outflows (Weiss and others, 1979; Jacobs and others, 1985; Potter and Paren, 1985; Schlosser and others, 1990) and to determine the transit time for sea water circulating beneath an ice shelf (Trumbore and others, 1991).

Evidence for basal freezing comes from radio-echo soundings and from coring and ice samples, most of which have been obtained from the central regions of the large ice shelves (Morgan, 1972; Neal, 1979; Zotikov and others, 1980; Engelhardt and Determann, 1987; Oerter and others, 1990). Modeling of the ocean circulation and glaciological field measurements also show net freezing in these areas, resulting from cooling of the ISW plumes to the in situ freezing point. However, data and models indicate that melting exceeds freezing for the mode 1 circulation (Hellmer and Olbers, 1989, 1991; Jenkins and Doake, 1991; Nicholls and others, 1991), as it must if thermohaline circulation is the dominant process which melts ice at depth, re-deposits some of it as marine ice, and exports potentially supercooled water and under- 


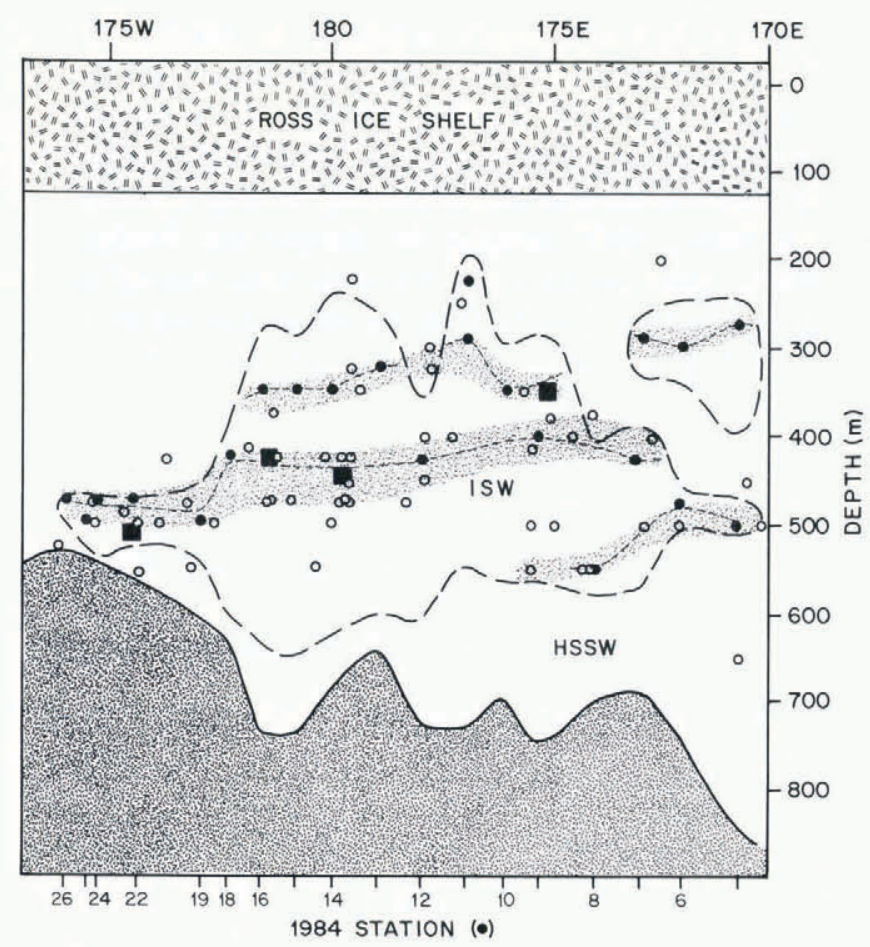

Fig. 3. In this east-west section near the Ross Ice Shelf front, the Ice Shelf Water (ISW) outflow over-rides highsalinity shelf water (HSSW) formed by winter surface freezing in the open Ross Sea. The ISW envelope is defined by parts of February 1984 vertical-temperature profiles that were colder than the sea-surface freezing point. Small circles denote local temperature minima on the vertical profiles taken during several austral summers, with the 1984 data (solid circles) joined by light-dashed lines. Large squares indicate the location of long-term (7-12 month) current measurements. The ice shelf has a shallow draft in this sector, which has not experienced a major calving event in several decades (Jacobs and others, 1986).

water ice from the sub-ice cavity (Robin, 1979; Dieckmann and others, 1986; Lewis and Perkin, 1986).

Oceanographic measurements can be used to estimate the amount of melting in the Ross Ice Shelf cavity. Vertical profiles along the western Ross Ice Shelf front in February 1984 showed an ISW plume cross-section of $72 \mathrm{~km}^{2}$ (Fig. 3). Current measurements extending over 712 month periods at four locations in this outflow (Pillsbury and Jacobs, 1985; Jacobs, 1991) all displayed net northward drift, which averaged $1.9 \mathrm{~cm} \mathrm{~s}^{-1}$. Applying this average velocity to the plume area corresponds to a northward transport of $1.4 \mathrm{~Sv}$ (1 Sverdrup $=10^{6} \mathrm{~m}^{3} \mathrm{~s}^{-1}$ ). The salinity difference between the 1984 outflow and the inflow a few years earlier (Jacobs, 1985) then yields a fresh-water component of $2 \%$. This assumes no freshwater transport by ice crystals and corresponds to a meltwater flux of $79 \mathrm{Gt}_{\text {year }}{ }^{-1}$, or $86 \mathrm{~km}^{3}$ year $^{-1}$ of ice at a density of $917 \mathrm{~kg} \mathrm{~m}^{-3}$. It equals a mean melt rate of $22 \mathrm{~cm}$ year $^{-1}$ (ice) over that part of the ice-shelf base more than $100 \mathrm{~km}$ from the ice front. This is somewhat larger than the $12-17 \mathrm{~cm}^{-1} \mathrm{ear}^{-1}$ estimates from glaciological and oceanographic models (Shabtaie and Bentley, 1987; Scheduikat and Olbers, 1990; Lingle and others, 1991).

Models of the ocean circulation and mass balance

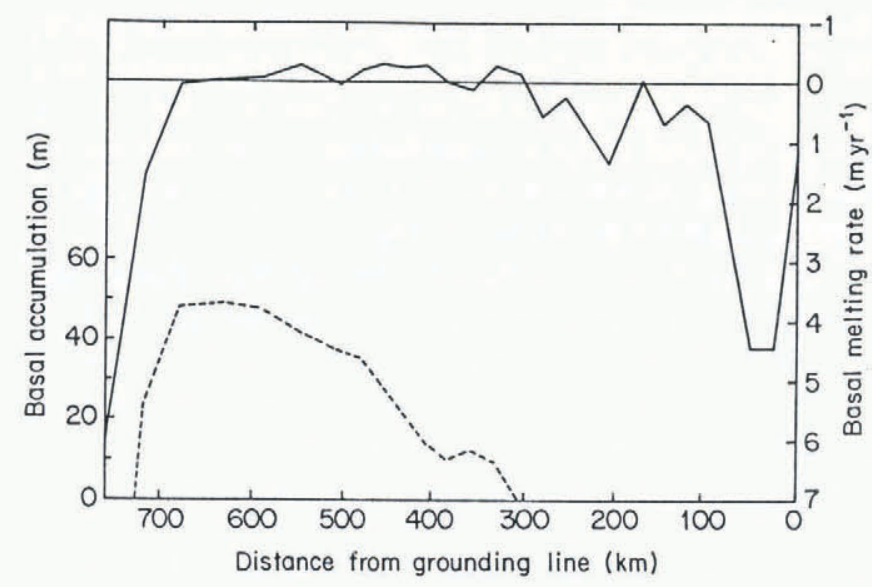

Fig. 4. Steady-state basal mass flux (solid line, right scale) calculated from glaciological field data at 28 sites along a Ronne Ice Shelf transect between the Rutford Ice Stream and the ice front. The dashed line shows the distribution of marine ice (left scale) deposited on the iceshelf base (Jenkins and Doake, 1991).

beneath the large ice shelves in the southern Weddell Sea show high melting near the grounding lines and widespread near-equilibrium conditions or marine ice accumulation over the central areas. Detailed glaciological studies at 28 sites along a $760 \mathrm{~km}$ transect across the Ronne Ice Shelf were used in a steady-state model by Jenkins and Doake (1991) to derive an average of $55 \mathrm{~cm}_{\text {year }}{ }^{-1}$ net melting for the region more than $85 \mathrm{~km}$ south of the ice front (Fig. 4). That transect begins at the $1500 \mathrm{~m}$ deep Rutford Ice Stream grounding line and passes to the west of a major sea-ice accumulation area on the Ronne Ice Shelf base. This freezing area is reproduced in a two-dimensional thermohaline ocean-circulation model applied to a long transect linking the sub-Ronne and Filchner Ice Shelf cavities around the southern end of

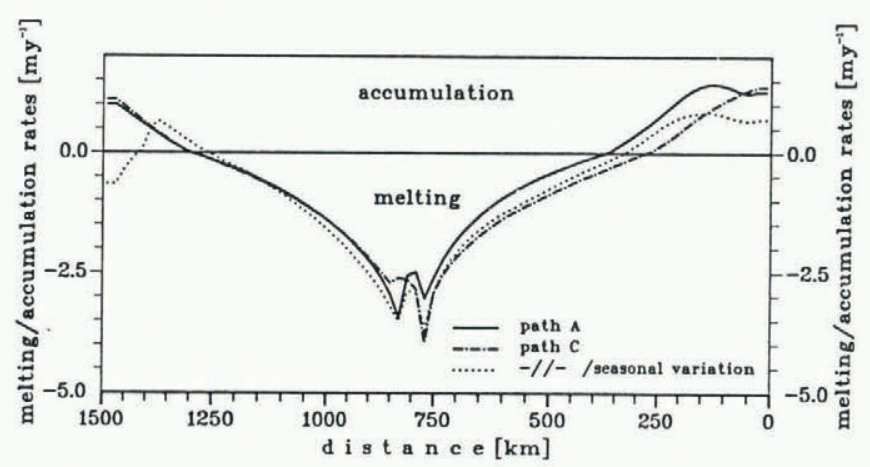

Fig. 5. Basal mass balance along two transects from the Filchner Ice Shelf front (left side), southward around Berkner Island to the Ronne Ice Shelf front (right side). Path A passes between Henry Ice Rise and Berkner Island; path $C$ along the western side of the Ronne Ice Shelf. The dotted line illustrates changes in the basal mass balance along path $C$ when the temperature and salinity are allowed to vary seasonally at the open boundaries. Tidal effects are not included and all ice crystals formed in the ISW are accumulated on the ice-shelf base (Hellmer and Olbers, 1991). 
Berkner Island (Hellmer and Olbers, 1991). That model extends an earlier Filchner Ice Shelf cavity simulation that had a shallower sub-ice shelf-water column and grounding line (Hellmer and Olbers, 1989), and shows net melting of $\sim 60 \mathrm{~cm} \mathrm{year}^{-1}$ in the region more than $100 \mathrm{~km}$ south of the ice front (Fig. 5).

The $55 \mathrm{~cm}$ year $^{-1}$ melt rate derived from Ronne Ice Shelf field measurements is equal to the removal of $202 \mathrm{Gtyear}^{-1}$ if extrapolated to the $400000 \mathrm{~km}^{2}$ interior Filchner-Ronne Ice Shelf region. For comparison, geochemical tracers from ocean stations along the Filchner ice front have shown 3-7\%o meltwater in ISW colder than $-2.0^{\circ} \mathrm{C}$ (Schlosser and others, 1990), or 95$222 \mathrm{Gtyear}^{-1}$ of melted ice for each Sv of outflow. This outflow feeds an ISW plume that overflows the continental shelf at a rate of $\sim 1 \mathrm{~Sv}$ at the north end of the Filchner Depression (Foldvik and others, 1985). These authors also showed ISW along the Ronne Ice Shelf front, and some ISW mixes down into the highsalinity shelf water (Weiss and others, 1979). A better spatial distribution of current measurements and seawater samples analyzed at modern geochemical precisions would allow more accurate calculations of the meltwater content and evolution of major water masses.

The smaller ice shelves produce less mode 1 meltwater, but illustrate a wider range of environments, including net basal freezing (Gow and Epstein, 1972; Souchez and others, 1991). Freezing of up to $60 \mathrm{~cm}$ year $^{-1}$ has been reported for the Amery Ice Shelf, supported by a thick layer of basal marine ice at the "Gl" drill site near $69^{\circ} 27^{\prime} \mathrm{S}, 71^{\circ} 42^{\prime} \mathrm{E}$ (Morgan, 1972; Budd and others, 1982). However, analyses of oxygen-isotope data (Robin, 1983) and observations of Ice Shelf Water in Prydz Bay (Zverev, 1959; Smith and others, 1984) suggest significant basal melting, as for the larger ice shelves. Modeling the sub-Amery ocean thermohaline circulation as a channel flow with seasonal forcing indicates a mean melting rate as high as $65 \mathrm{~cm}_{\text {year }}{ }^{-1}$ for this ice shelf (Hellmer and Jacobs, in press), equal to the removal of $23 \mathrm{Gt}$ year ${ }^{-1}$ of basal ice.

The second melting mode is dependent upon transport beneath the ice shelves of water that is substantially warmer than the surface freezing temperature. An oceanic heat source derived from the Circumpolar Deep Water (CDW) has been documented near several ice shelves and ice tongues (e.g. Jacobs and others, 1979; Foldvik and others, 1985) and has the potential to melt large volumes of basal ice. CDW about $3^{\circ} \mathrm{C}$ warmer than the in situ melting point flows beneath George VI Ice Shelf, which has a relatively high mean basal melt rate of $2.1 \mathrm{~m} \mathrm{year}^{-1}$ (Potter and Paren, 1985). Most of that water enters George VI Sound through Marguerite Bay, where it may have been a factor in the recent disintegration of the Wordie Ice Shelf (Doake and Vaughan, 1991). However, observed inflows elsewhere are less warm than in the Bellingshausen Sea, and can take the form of narrow currents at density horizons too shallow to reach the grounding lines. Heat transported beneath the ice in these more restricted currents can return as a warm outflow, perhaps contributing to mode 3 melting and to the maintenance of shelf polynyas (Jacobs and Comiso, 1989; Jacobs, 1991).

High basal loss rates near the ice fronts characterize
Table 1. Estimated in situ melting of the Antarctic ice shelves and grounded ice. The areas shown for the Filchner-Ronne and Ross Ice Shelves refer to regions $>100 \mathrm{~km}$ from their ice fronts. The $628000 \mathrm{~km}^{2}$ seaward of $100 \hat{\mathrm{km}}$ is the total area of floating ice shelf (Drewry and others, 1982; modified by Shabtaie and Bentley, 1987), minus the areas itemized in the table. Run-off is assumed to come from $2 \%$ of the top surface area and $50 \%$ of the grounded ice sheet, and ice density is taken as $917 \mathrm{~kg}$ $\mathrm{m}^{-3} .1 \mathrm{Gt}=10^{12} \mathrm{~kg}$

Source Area Melt rate Net melt $10^{3} \mathrm{~km}^{2} \quad \mathrm{~cm}_{\text {year }}{ }^{-1}$ Gt year ${ }^{-1}$

Ice-shelf basal melting:

$\begin{array}{lrrr}\text { Filchner-Ronne } & 400 & 55 & 202 \\ \text { Ross } & 400 & 22 & 79 \\ \text { George VI } & 25 & 210 & 49 \\ \text { Amery } & 39 & 65 & 23 \\ \begin{array}{l}\text { Within } 100 \mathrm{~km} \text { of } \\ \quad \text { ice fronts }\end{array} & 628 & 30 & 173 \\ & 3.5 & 500 & 18 \\ \text { Ice-shelf walls } & & & \\ & & \text { Ice-shelf sub-total } & 544\end{array}$

Run-off:

$\begin{array}{lrrr}\text { Top surface } & 240 & 15 & 36 \\ \text { Subglacial } & 6000 & 0.3 & 17\end{array}$

the third melting mode, as revealed by measurements on the ice and in the low-temperature, low-salinity coastal current (Jacobs and others, 1985). Measured temperature-depth profiles compared with steady-state calculations indicate basal melting of $70 \mathrm{~cm}_{\text {year }}{ }^{-1}$ at the eastern Ross Ice Shelf front, decreasing to $0 \pm 10 \mathrm{~cm} \mathrm{year}^{-1}$ $100 \mathrm{~km}$ southward (Thomas and MacAyeal, 1982). A linear decrease would correspond to an average melt rate of $30 \mathrm{~cm}_{\text {year }}{ }^{-1}$ in this zone, or $173 \mathrm{Gt} \mathrm{year}^{-1}$ when applied to the $628000 \mathrm{~km}^{2}$ area near all ice fronts (Table 1). The actual melt rate will vary regionally, and field measurements will differ from models that do not include factors such as tidal pumping or the transport of ice crystals out of the sub-ice cavity (Figs 4 and 5). The rate of wall melting is believed to exceed the rate of basal melting by an order of magnitude, ranging from 300 to $1400 \mathrm{~cm}$ year $^{-1}$ in the Antarctic (Neshyba and Josberger, 1980; Dubrovin and Preobrazhenskaia, 1985). Assuming $500 \mathrm{~cm}$ year $^{-1}$ sub-surface melting and subaerial weathering along $14000 \mathrm{~km}$ of floating coastline (Drewry and others, 1982) yields $18 \mathrm{Gt}_{\text {year }}{ }^{-1}$ for an average ice wall of $250 \mathrm{~m}$. 
' Surface run-off and outflow from beneath the grounded ice sheet are generally considered to be negligible, but remain to be accurately determined. About $2 \%$ of the grounded ice sheet is in the coastal ablation zone, and generates a surface run-off of $\sim 36 \mathrm{Gt}$ year $^{-1}$ (Robin, 1987). Melting occurs beneath some part of the grounded ice sheet from geothermal heat flux and glacier sliding (Zotikov, 1963; Radok and others, 1987; Engelhardt and others, 1990). If it averages $0.3 \mathrm{~cm}_{\text {year }}{ }^{-1}$ over half the grounded area, then as much as $17 \mathrm{Gt} \mathrm{year}^{-1}$ of basal meltwater could flow across the grounding line into the sea.

In situ melting and run-off are summarized in Table 1, with $544 \mathrm{Gtyear}^{-1}$ directly attributable to the ice shelves. This net value includes sub-ice-shelf freezing, explicitly from the model results and implicitly from its impact on ISW properties. The Filchner-Ronne Ice Shelf melting is 2.5 times that of the Ross Ice Shelf, perhaps consistent with higher ISW and bottom-water production rates in the Weddell Sea. We would also anticipate relatively more melting from the mode 1 circulation in the Weddell Sea due to the greater draft of the FilchnerRonne Ice Shelf vs the Ross Ice Shelf (Jenkins and Doake, 1991). The deep mode 1 circulation that contributes directly to bottom-water formation accounts for more than half of the total in Table 1. Ice-shelf melting is compared with several previous estimates in Table 2 (see also Buinitskii, 1964; Jacobs and others, 1985). It nearly equals accumulation on the ice shelves and is about onequarter of accumulation on the ice sheet.

\section{ACGURACY OF MELTING ESTIMATES}

Probable limits on melting beneath the ice shelves can be derived from several oceanographic and glaciological observations. In the Weddell Sea, a minimum of $1 \mathrm{~Sv}$ of ISW with a meltwater component of at least 3\%o (melting of $95 \mathrm{Gtyear}^{-1}$ ) is needed to provide the overflow measured at the shelf break. At this ISW production rate, the maximum meltwater component of $7 \%$ corresponds to a melt rate of $222 \mathrm{Gtyear}^{-1}$. That approximates the ice flux across the Filchner-Ronne Ice Shelf grounding line (Giovinetto and Bentley, 1985), and would imply the removal of most land ice before the ice front is reached. In fact, radio-echo soundings on the Ronne Ice Shelf have shown a basal marine layer overlain by relatively little glacial ice (Oerter and others, 1990), most of which might be accounted for by precipitation on the ice shelf. This is analogous to the findings from an oxygen-isotope profile through the Shackleton Ice Shelf, which revealed neither land nor marine ice (Savatiugin and Vaikmae, 1990).

The Ross Sea ISW outflow could be overestimated if parts of it recirculate beneath the ice shelf, as may occur near the Ronne Ice Shelf (Weiss and others, 1979; Foldvik and others, 1985). A meltwater flux of $40 \mathrm{Gt} \mathrm{year}^{-1}$ is consistent with lower estimates of basal melting from glaciological models (Shabtaie and Bentley, 1987; Lingle and others, 1991) and would correspond to approximately $50 \%$ of the ISW. Biases resulting from the predominance of summer observations or the spatial

Table 2. Primary components of Antarctica's ice budget, in $\mathrm{Gt} \mathrm{year}^{-1}$, from previous and present analyses. Some accumulation estimates do not include the Antarctic Peninsula, and some components are averages of the ranges given. The components attributed to Meier (1983), e.g. were averaged from seven prior studies in his table 3. The Losev (1963) calving estimate is a minimum, subsequently revised to -2600 (Losev, 1973). Barkov's calving estimate applied only to ice shelves. We have taken accumulation to be accurate to $\pm 20 \%$, and estimate errors of $\pm 33 \%$ for iceberg calving and $\pm 50 \%$ for ice-shelf melting and run-off. See text, Table 1 and Figure 7

\begin{tabular}{|c|c|c|c|c|c|c|c|}
\hline \multicolumn{3}{|c|}{ Accumulation } & \multicolumn{3}{|c|}{ Attrition } & Balance & Reference \\
\hline $\begin{array}{c}\text { Grounded } \\
\text { ice }\end{array}$ & $\begin{array}{c}\text { Ice } \\
\text { shelf }\end{array}$ & Total & $\begin{array}{l}\text { Calving } \\
\text { icebergs }\end{array}$ & $\begin{array}{c}\text { Ice-shelf } \\
\text { melting }\end{array}$ & Run-off & & $1956-67$ \\
\hline
\end{tabular}

\begin{tabular}{|c|c|c|c|c|c|c|c|}
\hline \multirow{7}{*}{1490} & \multirow{7}{*}{356} & 1749 & -855 & -251 & & +487 & Meier (1983) \\
\hline & & 2000 & -1700 & -550 & & -400 & Losev (1963) \\
\hline & & 1885 & -1053 & -293 & & & Barkov (1971) \\
\hline & & 2080 & -1450 & -200 & -10 & +420 & Bull (1971) \\
\hline & & 2000 & -2400 & -320 & -60 & -720 & Kotlyakov and others (1978) \\
\hline & & 2000 & -1800 & & & +200 & Budd and Smith (1985) \\
\hline & & & -2300 & & & - & Orheim (1985) \\
\hline 1468 & 495 & 1963 & & & & & Giovinetto and Bentley (1985) \\
\hline & & 2141 & & & & & Giovinetta and Bentley (1989) \\
\hline 1817 & 287 & 2104 & & & & & Fortuin and Oerlemans (1990) \\
\hline & & 2200 & -2200 & & & 0 & Warrick and Oerlemans (1990) \\
\hline 1660 & & & & & & +180 & Bentley and Giovinetto (1991) \\
\hline 1528 & 616 & 2144 & -2016 & -544 & -53 & -469 & This study \\
\hline
\end{tabular}


distribution of current meters could influence the calculations either way. Unaccounted for would be meltwater outflows displaced from or less cold than the primary ISW plume in Figure 3, or associated with the mode 2 recirculation cell. Utilizing a summer-average shelf-water salinity rather than the lowest-salinity 1982 data for the cavity inflow would increase melting by $73 \%$ (to $137 \mathrm{Gt} \mathrm{year}^{-1}$ ).

The other large budget item, melting beneath the seaward $100 \mathrm{~km}$ of ice shelves, could be reduced by assuming a more rapid landward decay of the $70 \mathrm{~cm}$ year $^{-1}$ rate at the ice front (Zotikov, 1986). This would confine most melting to the outer few tens of kilometers and give a mean value of $20-25 \mathrm{~cm}$ year $^{-1}(110-140 \mathrm{Gt}$ year $^{-1}$ ) for the seaward $100 \mathrm{~km}$ zone. On the other hand, our assumed $70 \mathrm{~cm}$ year ${ }^{-1}$ melt rate at the ice front, derived from the eastern Ross Ice Shelf, is lower than many previous findings (references in Jacobs and others $(1985,1986))$. Doubling this zonal average to $60 \mathrm{~cm}$ year $^{-1}$ (346 Gtyear ${ }^{-1}$ ) might better account for the predominance of smaller, more northerly ice shelves in this $100 \mathrm{~km}$ zone (e.g. Kipfstuhl, 1991). Combining these limits suggests that total ice-shelf melting could be as much as $50 \%$ higher or lower than our best estimate. Uncertainties in the smaller attrition terms may differ from this percentage, but they have a relatively small impact on the net balance.

\section{ICEBERG CALVING}

Calving of icebergs is the largest factor in the attrition of the Antarctic ice sheet, the perimeter of which extends to its various ice fronts. Attempts to quantify the icebergproduction rate are usually compromised by uncertainties in estimating sizes, ocean area surveyed and typical lifetimes, or by the difficulties of accounting for duplicate sightings, seasonal and areal variability, and attrition between the time of calving and observation. An international iceberg census program endorsed by the Scientific Committee on Antarctic Research (SCAR) has been under way for some time on ships of opportunity, with data management at the Norsk Polarinstitutt. The initial results from that project indicated a production rate of $2300 \mathrm{Gtyear}^{-1}$ between 1977 and 1984, assuming an average lifetime of 4 years, an ice density of $800 \mathrm{~kg} \mathrm{~m}^{-3}$ and a typical thickness of $300 \mathrm{~m}$ (Orheim, 1985). The Filchner-Ronne Ice Shelf and Ross Ice Shelf fronts were known to be advancing without significant calving during that period (Lange and Kohnen, 1985; Jacobs and others, 1986), thus contributing little to the calculated iceberg volume. However, these large features and the smaller Amery Ice Shelf account for only one-third of the icesheet outflow by volume (Giovinetto and Bentley, 1985) since they drain the low-precipitation continental interior. In terms of calving volume and ocean area per iceberg, the Norsk Polarinstitutt estimate was broadly consistent with other findings since 1970 (Kotlyakov and others, 1978; Weeks and Mellor, 1978; Wadhams, 1988; Table 2).

An update on the Norsk Polarinstitutt/SCAR census project (Orheim, 1990) indicated that the production rate of small icebergs (main axis $<28 \mathrm{~km}$ ) was nearly constant for the preceding several years and that the total mass exceeded that of large icebergs $(>28 \mathrm{~km}$ ) calved during the same interval. Volumetric information can readily be derived for the large icebergs, which have been identified from satellite data for more than a decade by the U.S. Navy-NOAA Joint Ice Center (NNJIC, 1973-90). We approximated these iceberg areas from the NNJIC dimensions, in a few cases substituting available areas derived from Landsat data (Ferrigno and Gould, 1987). Anticipating that the greatest lengths and widths may often be reported, we used elliptical areas in an attempt to avoid size exaggeration. Iceberg mass was then obtained by assuming an average thickness of $250 \mathrm{~m}$ and a mean density of $850 \mathrm{~kg} \mathrm{~m}^{-3}$ (see also Morgan and Budd, 1978; Weeks and Mellor, 1978; Keys and others, 1990). This is a lower density than employed above for the bottoms of ice shelves, but consistent with a mean density of $841 \mathrm{~kg} \mathrm{~m}^{-3}$ near the front of the Ross Ice Shelf (Crary and others, 1962) and with $863 \mathrm{~kg} \mathrm{~m}^{-3}$ that can be inferred for icebergs from equation (1) in Jenkins and Doake (1991). These assumptions result in a mean large iceberg calving rate of $1008 \mathrm{Gtyear}^{-1}$ for the 1979-90 period in Figure 6. A small iceberg production rate $>1200 \mathrm{~km}^{3}$ year $^{-1}$ would be consistent with results of the ongoing Norsk Polarinstitutt project (personal communication from O. Orheim, 1991). With our assumed density this suggests a minimum value very close to the 1979-90 large iceberg calving rate. We therefore interpret Orheim (1990) conservatively and use the value $1008 \mathrm{Gt} \mathrm{year}^{-1}$ for the small iceberg production rate as well. The resulting total calving of $2016 \mathrm{Gt}_{\text {year }}{ }^{-1}$ is slightly lower than the $2175 \mathrm{Gt}_{\text {year }}{ }^{-1}$ average of four other estimates since the mid-1970s (Table 2).

The major uncertainties in our large iceberg calving estimates are event frequency and volume determination. Without a longer record, we cannot assess the expected

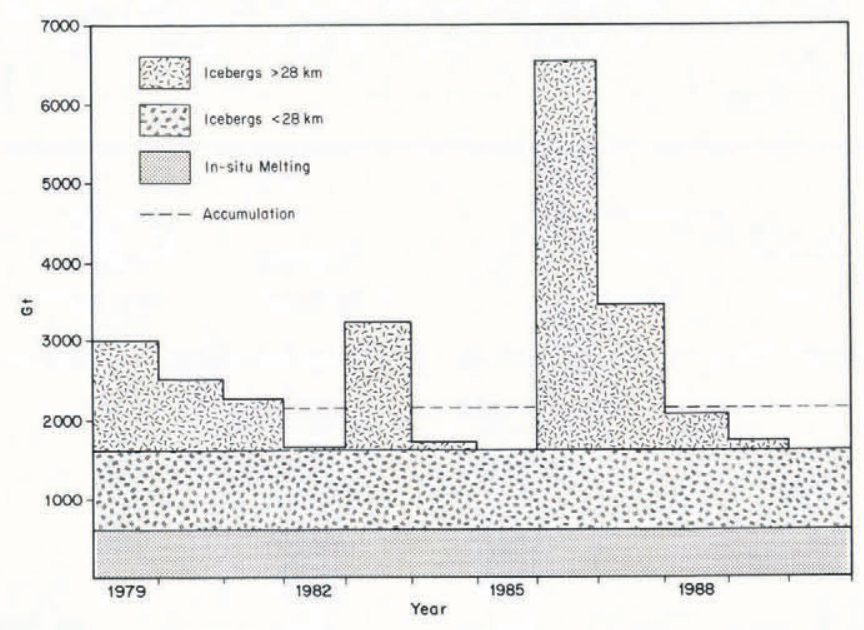

Fig. 6. Annual calving of large icebergs (one dimension $>28 \mathrm{~km}$ ) superimposed on 1979-90 average production of smaller icebergs and in situ melting of the Antarctic ice sheet. The iceberg data are from NOAA, DMSP and Landsat-satellite imagery, and from shipboard observations. Accumulation is from Giovinetto and Bentley (1985), adjusted to include the Antarctic Peninsula. $1 \mathrm{Gt}=10^{12} \mathrm{~kg}=1 \mathrm{~km}^{3}$ fresh-water equivalent. See text and Tables 1 and 2. 
frequency of the very large calving events, which here contribute about $38 \%$ to the large-iceberg volume. However, these 1986-87 break-outs represented less than $600 \mathrm{~km}$ of the glaciated coastline and are not as anomalous as might be supposed. While major calving may not re-occur in these sectors for several decades, more than $14000 \mathrm{~km}$ of ice-shelf front (Drewry and others, 1982) are available for these infrequent events. There are several accounts of major calving activity prior to 1979, a start date we selected because NNJIC observations became more systematic at that time. Taking very large events to be those with iceberg areas greater than $2000 \mathrm{~km}^{2}$, then six icebergs with a combined area $>22000 \mathrm{~km}^{2}$ calved from 1967 to 1978 (NNJIC, 197378; Swithinbank and others, 1977; McIntyre and Cudlip, 1987). For comparison, five icebergs with an area of $21527 \mathrm{~km}^{2}$ calved during our equal-length study period (1979-90 in Figure 6). Prior to 1967 only random shipboard sightings are available and these can be quite inaccurate (Jacobs and Barnett, 1987). Furthermore, even giant icebergs have rather brief lifetimes north of the continental shelf and most would probably have been missed in the infrequently travelled Antarctic Circumpolar Current. Recent satellite coverage and greater ship traffic may account for generally higher calving estimates now than two decades ago.

Potential volumetric errors suggest that average calving could be roughly one-third higher or lower than we have estimated for 1979-90. For example, if we assume that many of these tabular Antarctic icebergs had rectangular shapes (vs elliptical) and $275 \mathrm{~m}$ average thicknesses (vs $250 \mathrm{~m}$ ), that would increase the largeiceberg volume by up to $37 \%$. Alternatively, it might be supposed that iceberg dimensions obtained from weathersatellite images are systematically overstated, since elliptical areas for the 1986 Filchner Ice Shelf and 1987 Ross Ice Shelf large icebergs would nearly match the Landsat-derived areas if the NNJIC dimensions were reduced by $10-15 \mathrm{~km}$. Similar reductions applied to all of the large icebergs could decrease their volume by as much as $36 \%$. A similar range in estimates of small iceberg production would arise from assuming average lifetimes between three and six years, which would include most estimates. Freely drifting icebergs are unlikely to survive as long as six years, but many small ones are beset for unknown periods in fast ice (see coastal Landsat images in Swithinbank (1988)).

\section{ICE-SHEET MASS BALANCE}

An earlier review of accumulation on the ice sheet (Giovinetto and Bentley, 1985) has been adjusted in this analysis to include the Antarctic Peninsula. Following their nomenclature, we added 73.0, 9.9 and 14.2 $\mathrm{Gt} \mathrm{year}^{-1}$ in the I-J sector for grounded ice, ice rises and islands, and ice shelves, respectively, and $87.0 \mathrm{Gt} \mathrm{year}^{-1}$ for ice shelves, islands and rises in the $\mathrm{H}^{\prime}-\mathrm{I}$ sector (Frolich, 1992). The resulting total of $2144 \mathrm{Gtyear}^{-1}$ is consistent with other recent determinations (Table 2), and is approximately equal to the mean of 12 1971-85 studies evaluated by Giovinetto and Bentley (1989). Subtracting from the total accumulation our estimates of ice-shelf melting, run-off and iceberg calving results in a balance of $-469 \mathrm{Gt} \mathrm{year}^{-1}$. This large negative result is presaged by the Soviet and Norwegian findings (Table 2), but is it significantly different from zero? If so, are the ice shelves thinning or is the floating perimeter of Antarctica retreating toward the interior, particularly in the Antarctic Peninsula area (Doake, 1985; Korotkov and Romanov, 1990; Doake and Vaughan 1991)? Alternatively, are the ice-shelf fronts and thicknesses in equilibrium, maintained by excess flow across the grounding line? In this case, the grounded ice sheet would be slowly losing some of its volume to the sea.

It cannot be demonstrated with certainty that the calculated negative mass balance differs significantly from ice-sheet equilibrium. Underlying estimates are derived from carefully selected but limited local measurements extrapolated over wider regional areas. For example, Giovinetto and Bentley $(1985,1989)$ evaluated numerous compilations of regional surface mass balance and came up with an ice-sheet rate $\sim 8 \%$ lower than would have been obtained from the mean of 12 other estimates since 1971. The higher average would only account for $171 \mathrm{Gtyear}^{-1}$ of our imbalance. The observation periods

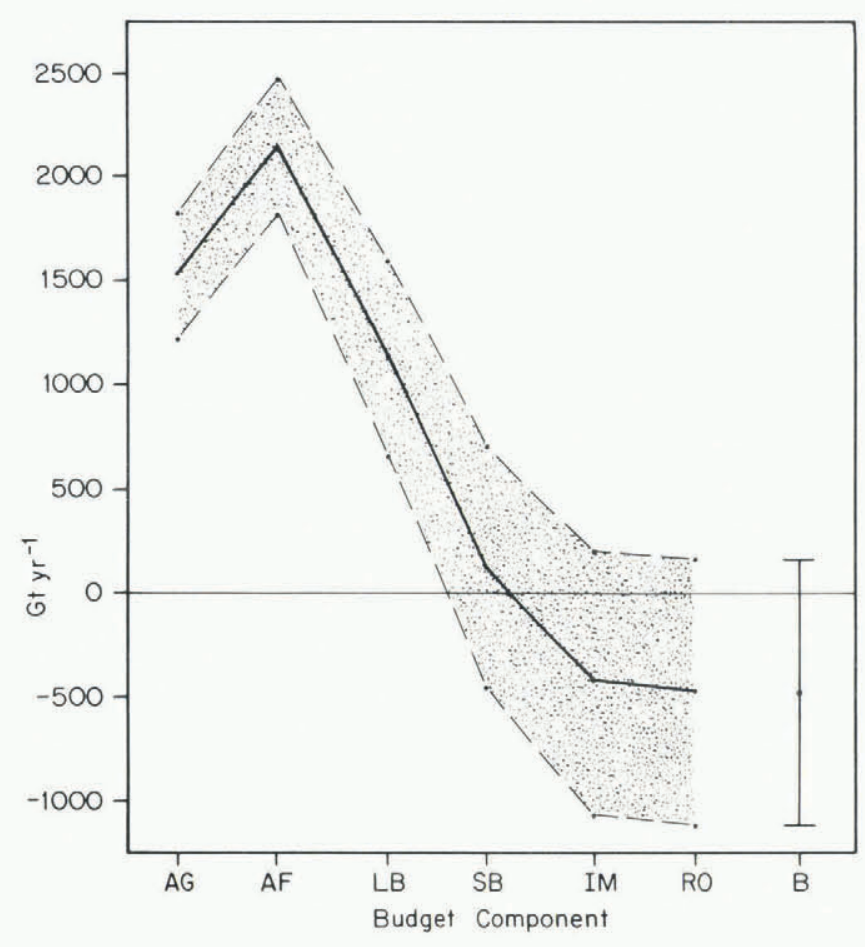

Fig. 7. Cumulative growth and attrition components for the annual Antarctic ice-sheet budget, with associated error estimates in the shaded band. Accumulation is apportioned between grounded and floating ice ( $A G$ and $A F)$, calving between large and small icebergs ( $L B$ and $S B$ ), and melting between basal ice shelf and run-off (IM and RO). Heuristic errors for each budget component, from Table 2, are taken to be estimates of the standard deviations of each term, so that an estimate of the variances is their squared value. Since the balance B $(-469 \mathrm{Gt}$ year $\left.{ }^{-1}\right)$, is a sum of individual terms, the variance of the balance is the sum of the variance of the components. The square root of the balance variance is the estimate of balance error, which ranges from +170 to $-1108 \mathrm{Gt}$ year $^{-1}$. This will be an underestimate if the terms are not independent. 
are short in relation to the probable natural variability of individual budget components, as illustrated by the large iceberg-calving record (Fig. 6). We have combined the estimates of error in Figure 7, but these first-order approximations may change substantially when more accurate data become available. The balance uncertainty is consistent at one end of its range with recent estimates of ice-sheet growth (Budd and Smith, 1985; Polar Research Board, 1985; Bentley, 1989; Meier, 1990). Nevertheless, our calculations strongly suggest a negative ice-sheet mass balance for at least the past decade. Further, they highlight the importance of ice-shelf melting, which has usually been underestimated in previous analyses.

If an Antarctic ice sheet imbalance of $-469 \mathrm{Gt} \mathrm{year}^{-1}$ is taken to be a reasonable estimate for the past decade or so, is that rate of shrinkage likely to have been noticed in elevation or perimeter changes? By arbitrarily assuming that the loss was evenly distributed between perimeter recession and grounded-ice elevation change, it can be apportioned between a coastline of $14000 \mathrm{~km} \times 250 \mathrm{~m}$ and a grounded-ice area of $12 \times 10^{6} \mathrm{~km}^{2}$. That would correspond to a retreat of $\sim 0.08 \mathrm{~km} \mathrm{year}^{-1}$, an order of magnitude less than typical ice-front advance rates. In recent years, some ice fronts have dramatically receded (Doake, 1985; Ferrigno and Gould, 1987; Keys and others, 1990; Korotkov and Romanov, 1990; Doake and Vaughan, 1991) and others have steadily advanced (Lange and Kohnen, 1985; Jacobs and others, 1986; MacDonald and others, 1989). Zakharov (1988) reviewed evidence for ice-shelf fluctuations over the past 100 years, but did not report net perimeter changes. The corresponding elevation decrease of $\sim 2 \mathrm{~cm}_{\text {year }}^{-1}$ is half the estimated $20 \%$ accuracy of accumulation measurements and might not be detected for many years, with or without more comprehensive and accurate satellite data. If it were postulated that the recent imbalance has persisted for the past century, then today's average icefront position and ice-sheet elevation would be only $8 \mathrm{~km}$ farther south and $2 \mathrm{~m}$ lower than 100 years ago. These rough measures illustrate that historical records of perimeter location and elevation are unlikely to be of much assistance in resolving this imbalance.

\section{TEMPORAL VARIABILITY}

The break-out of very large icebergs from Antarctica is believed to occur on time-scales of several decades at any given site. The overall calving rate is not constant, and may be related to changes in ice flux across the grounding line. Less variability might be expected for the in situ melting rate, if the ocean circulation is stable and buffered near the coastline by large volumes of sea water at the seasurface freezing temperature (MacAyeal, 1984b). However, quite large inter-annual thermohaline changes have occurred in shelf waters along the Ross Ice Shelf front in the two decades since the late 1960s, including a general shift toward lower salinities (Jacobs, 1985). Lower salinity can result from other factors than increased basal melting, such as less sea-ice formation or a shorter residence time of the shelf water. Some regional trends toward less sea ice have been noted (Weatherly and others, 1991), and the annual duration of sea-ice cover fluctuates by several weeks in the Ross Sea (Jacobs and Comiso, 1989). Total Antarctic sea-ice area and extent appears not to have changed significantly during the 1978-87 period (Gloersen and Campbell, 1991).

The modeled ocean circulation beneath an ice shelf depends strongly upon the shape of the sub-ice cavity and is sensitive to small changes in the properties of inflowing sea water. Temperature and salinity variations of only $0.02\left({ }^{\circ} \mathrm{C}\right.$ and \%o) caused $\sim 10 \mathrm{~cm}$ year $^{-1}$ shifts in the net basal melting along a Filchner Ice Shelf transect (Hellmer and Olbers, 1989). Seasonal forcing of a longer FilchnerRonne Ice Shelf transect (path C in Figure 5) also shifted the melting and freezing rates, particularly near the ice fronts. The thermohaline variability assumed in those models is substantially less than observed seasonally and inter-annually in the Ross Sea. Any accompanying changes in the strength of the ocean circulation could translate into basal mass-balance changes deep within the sub-ice cavities, i.e. near the grounding lines. If the West Antarctic ice sheet is vulnerable to accelerated retreat of grounding lines into deep subglacial basins (Hughes, 1973), the melting potential provided by the thermohaline circulation and the pressure dependence of seawater freezing temperature could be important factors in that process. It is also possible that dense, saline water near the in situ freezing point accumulates in sub-ice shelf depressions, limiting the penetration of warmer water to the grounding line. Such briny deeps could result if intense freezing in basal hinge-line crevasses overwhelms subglacial meltwater flow and produces a strong pycnocline beneath the mode 1 thermohaline circulation.

Over the past several years, general circulation model (GCM) simulations have led to predictions of significant future changes in ocean temperature and sea-ice cover near Antarctica (e.g. Schlesinger, 1985; Hansen and others, 1988). Large GCM grids limit the utility of these models to depict the region very near Antarctica, leading to features that seem anomalous without changes in the present-day ocean circulation. For example, a circumpolar warming in excess of $0.5^{\circ} \mathrm{C}$ to depths of more than $2000 \mathrm{~m}$ over the Antarctic continental slope (Stouffer and others, 1989) occurs in a region now dominated by strong contour currents and deep vertical convection. This circulation could weaken if the Southern Ocean were warmer and receiving more precipitation than at present. That might allow more sea-ice cover and a shift toward an Arctic-type climate, where the present-day vertical heat flux from ocean to atmosphere is an order of magnitude less than in the Antarctic (Gordon, 1983). If less oceanic heat were to upwell into the mixed layer, would more be transported on to the deep continental shelves? Would this cause an increase in the second mode of ocean-ice-shelf interaction, now volumetrically small except beneath ice shelves in the Bellingshausen Sea? Or will a warm atmosphere lead to less sea-ice formation, less brine release on the continental shelf, less of the mode 1 type of ice-shelf melting and less bottom-water production? More complete field data and improved oceanatmosphere model coupling will be necessary to answer these questions.

Over the past sevcral decades, local precipitation or surface-air temperature increases have been recorded at a 
number of Antarctic sites (Pourchet and others, 1983; Peel and Mulvaney, 1988; Jacka, 1990; Jones, 1990; Morgan and others, 1991; Weatherly and others, 1991). The Vostok ice-core data suggest substantially lower snow accumulation on Antarctica during the last glacial maximum (Lorius and others, 1989), and initial satellite-altimeter analyses are suggestive of recent regional elevation increases (Partington and others, 1991). Greater precipitation rates are generally expected to accompany a warmer climate, and could account for an increase of 3-4 cm year ${ }^{-1}$ on the ice sheet by the year $\mathrm{AD} 2050,25 \%$ or more above current levels (Robin, 1987). That would roughly balance the mass deficit reported here, except that increased temperature and accumulation may be accompanicd by increased calving and basal melting (Jenkins, 1991; Lingle and others, 1991). Regional evidence also exists for decreases in precipitation and ice-sheet elevation or thickness (Shabtaie and Bentley, 1987; Whillans and others, 1987; Graf and others, 1990; Kameda and others, 1990). Furthermore, some GCM simulations now project reduced atmospheric warming at high southern latitudes, in part because of more heat uptake by the greater ocean area in that hemisphere (Stouffer and others, 1989). Given that the rate of ice-shelf melting is highly sensitive to ocean temperature, will the ocean's loss become the ice sheet's loss?

\section{THE SEA-LEVEL CONNECTION}

Once glacier ice has crossed a grounding line, its primary contribution to sea-level change has been made. As noted above, several recent analyses have indicated that Antarctica's grounded-ice budget is positive but, in fact, it is not yet possible accurately to monitor elevations over the entire ice sheet or the total annual transport of ice across the grounding line. Satellite sensors have shown considerable promise in the mapping of Antarctic ice fronts and elevations, and future satellites in polar orbits should provide the data necessary for more complete evaluations (Thomas and others, 1983; Thomas, 1987; Zwally and others, 1987; Partington and others, 1991). In the interim, it should be noted that a negative budget for floating plus grounded ice is not necessarily in conflict with estimates of a positive budget for the grounded ice alone. But, if the floating parts are receding or thinning, that must eventually lead to greater discharge across the grounding line. Thus, any present-day damping of sealevel rise by growth of the ice sheet (Bentley and Giovinetto, 1991) cannot be expected to continue indefinitely with recent patterns of precipitation and attrition. Alternatively, flow of ice off the land may roughly balance attrition of ice in contact with the ocean, in which case the implied negative balance for the grounded ice can be directly related to recent sea-level change.

Sea level has risen an average of $6 \mathrm{~mm}$ year $^{-1}$ since the last glacial maximum, at times as rapid as 20$40 \mathrm{~mm}$ year $^{-1}$ (Fairbanks, 1989), primarily in response to melting of Northern Hemisphere ice sheets. The change has been slower over the past several thousand years, and most estimates for the past century show a rise of 1-1.5 mmyear ${ }^{-1}$ (e.g. Gornitz and others, 1982; Barnett, 1990). A somewhat faster rate (1.8$2.4 \mathrm{~mm}$ year $^{-1}$ ) has been estimated over shorter periods from models that incorporate sea-level records and glacial isostatic adjustments (Douglas, 1991; Peltier and Tushingham, 1991). The recent rise is generally attributed to ocean thermal expansion that would have resulted from a rise in air temperature, the retreat of temperate glaciers, shifts between the ocean and fresh-water reservoirs (Gornitz and others, 1982; Meier, 1984, 1990), and a negative ice budget for Greenland. The annual ice budget for Greenland is much smaller than that for Antarctica and could also be positive (Reeh, 1985; Zwally, 1989; Braithwaite and Olesen, 1990). Warrick and Oerlemans (1990) evaluated the most probable contributions to global sea-level rise over the past 100 years for the Intergovernmental Panel on Climate Change (IPCC), estimating $0.4 \mathrm{mmyear}^{-1}$ from thermal expansion, $0.4 \mathrm{mmyear}^{-1}$ from glaciers and small ice caps, $0.25 \mathrm{mmyear}^{-1}$ from the Greenland ice sheet and $0.0 \mathrm{~mm}$ year $^{-1}$ from Antarctica. That left the remaining 0.45 mmyear $^{-1}$ of a $1.5 \mathrm{mmyear}^{-1}$ "best estimate" unaccounted for. If the actual rise has been only $1 \mathrm{~mm}$ year $^{-1}$, then it can largely be accounted for by thermal expansion and the melting of non-polar ice (Church and others, 1991). If the rise has been in the $1.8-2.4 \mathrm{~mm}_{\text {year }}{ }^{-1}$ range cited above, then a deficit around $1 \mathrm{~mm}$ year $^{-1}$ has yet to be explained.

Each millimeter of global sea-level rise is roughly equal to the addition of $360 \mathrm{Gt}$ of water to the ocean. That is less than $20 \%$ of the $2144 \mathrm{Gtyear}^{-1}$ annual accumulation on the Antarctic ice sheet (Table 2). The $-469 \mathrm{Gtyear}^{-1}$ imbalance between accumulation and attrition would be equivalent to a sea-level rise of $1.3 \mathrm{~mm}$ year $^{-1}$ if it all came from the grounded ice. This seems unlikely, but as yet we cannot apportion the imbalance between grounded and floating regions of the ice sheet with any certainty. The brief records do not inspire great confidence in the result, and the error band in Figure 7 suggests a balance uncertainty as large as $639 \mathrm{Gt} \mathrm{year}^{-1}$. It is of interest, however, that considerably less than half of the mass-balance deficit need be derived from grounded parts of the ice sheet to make up the unexplained $0.45 \mathrm{~mm}$ year ${ }^{-1}$ of recent sea-level rise.

Three decades ago, it was observed that the lack of data on long-period changes made it risky to conclude that the volume of Antarctic ice is either increasing or decreasing (Wexler, 1961). Recent progress reported here confirms estimates made since that time of considerable basal melting of ice shelves (Buinitskii, 1964; Thomas and Coslett, 1970; Robin, 1979). If present accumulation and calving estimates are correct, this melting is sufficient to cause a negative ice-sheet mass balance of about $20 \%$. Continued field measurements, satellite observations and model development should extend the brief records now available, reduce the major uncertainties and help determine the likely persistence of the present disequilibrium condition.

\section{ACKNOWLEDGEMENTS}

We thank B. Batchelder, C. Bentley, A. Gordon, J. 
Kipfstuhl, B. Molfino, O. Orheim and P. Schlosser for helpful comments and other assistance with the manuscript. This work was initiated by "SeaRISE" Workshops organized at NASA by R. Bindschadler and sponsored by the U.S. National Science Foundation, and was supported by grants from NASA (NAGW-1344), U.S. NSF (DPP-90-08906), and through a Columbia University post-doctoral fellowship to H.H.H. LamontDoherty Geological Observatory contribution \#4978 .

\section{REFERENCES}

Allison, I. , ed. 1981. Sea level, ice and climatic change. Proceedings of the Symposium held 7-8 December 1979. International Association of Hydrological Sciences Publication 131 (Symposium at Canberra 1979 - Sea Level, Ice and Climatic Change).

Barkov, N. I. 1985. Ice shelves of Antarctica. Rotterdam, Balkema.

Barnett, T.P. 1990. Recent changes in sea level: a summary. In Sea-level change. Studies in geophysics. Washington, DC, National Academy Press, 37-51.

Bentley, C. R. 1989. The current mass balance of the Antarctic ice sheet. [Abstract.] Eos, 70(43), 1002.

Bentley, C. R. and M. B. Giovinetto. 1991. Mass balance of Antarctica and sea level change. In Weller, G., C. L. Wilson, and B.A.B. Severin, eds. Polar Regions and Climate Change. Proceedings of Symposium, University of Alaska, Fairbanks, June, 1990, 481-488.

Braithwaite, R.J. and O.B. Olesen. 1990. Increased ablation at the margin of the Greenland ice sheet under a greenhouse-effect climate. Ann. Glaciol., 14, 2022.

Budd, W. F. and I. N. Smith. 1985. The state of balance of the Antarctic ice sheet - an updated assessment 1984. In Polar Research Board, ed. Glaciers, Ice Sheets, and Sea Level: Effect of a $\mathrm{CO}_{2}$-induced Climatic Change. Report of a Workshop held in Seattle, Washington, September 13-15, 1984. Washington, DC, National Academy Press, 172-177.

Budd, W.F., M.J. Corry and T.H. Jacka. 1982. Results from the Amery Ice Shelf Project. Ann. Glaciol., 3, 3641.

Bull, C. 1971. Snow accumulation in Antarctica. In Quam, L.O., ed. Research in the Antarctic. Washington, DC, American Association for the Advancement of Science, 367-421. (Publication 93.)

Buynitskiy, V.K. 1964. Dvizhenye i balans massy shel'fovykh l'dov Antarktiki [Movement and mass balance of Antarctic ice shelves]. Vestn. Leningradskogo Universiteta Geol. Geogr., 6(1), 57-70.

Church, J.A., J.S. Godfrey, D. R. Jackett and T.J. McDougall. 1991. A model of sea level rise caused by ocean thermal expansion. F. Climate, 4(4), 438-456.

Crary, A. P. 1961. Glaciological regime at Little America Station, Antarctica. 7. Geophys. Res., 66(3), 871-878.

Crary, A. P., E. S. Robinson, H. F. Bennett and W. W. Boyd, Jr. 1962. Glaciological studies of the Ross Ice Shelf, Antarctica, 1957-60. IGY Glaciol. Rep. 6.

Dieckmann, G., G. Rohardt, H. Hellmer and J. Kipfstuhl. 1986. The occurrence of ice platelets at $250 \mathrm{~m}$ depth near the Filchner Ice Shelf and its significance for sea ice biology. Deep-Sea Res., 33(2A), 141-148.

Doake, C. S. M. 1976. Thermodynamics of the interaction between ice shelves and the sea. Polar Rec., 18(112), 3741.

Doake, C. S. M. 1985. Antarctic mass balance: glaciological evidence from Antarctic Peninsula and Weddell Sea sector. In Polar Research Board, ed. Glaciers, Ice Sheets, and Sea Level: Effect of a $\mathrm{CO}_{2}$-induced Climatic Change. Report of a Workshop held in Seattle, Washington, September 13-15, 1984. Washington, DC, National Academy Press, 197-209.

Doake, C. S. M. and D. G. Vaughan. 1991. Rapid disintegration of the Wordie Ice Shelf in response to atmospheric warming. Nature, 350(6316), 328-330.

Douglas, B. C. 1991. Global sea level rise. 7. Geophys. Res., 96(C4), 6981-6992.

Drewry, D.J., S.R. Jordan and E. Jankowski. 1982. Measured properties of the Antarctic ice sheet: surface configuration, ice thickness, volume and bedrock characteristics. Ann. Glaciol., 3, 83-91.

Dubrovin, L.I. and M.A. Preobrazhenskaia. 1985. Thermal action of coastal waters on the boundary of the Antarctic ice cover. Probl. Arct. Antarct., 59, 101108.

Engelhardt, H. and J. Determann. 1987. Borehole evidence for a thick layer of basal ice in the central Ronne Ice Shelf. Nature, 327(6120), 318-319.

Engelhardt, H., N. Humphrey, B. Kamb and M. Fahnestock. 1990. Physical conditions at the base of a fast moving Antarctic ice stream. Science, 248(4951), $57-59$

Fairbanks, R. G. 1989. A 17,000-year glacio-eustatic sea level record: influence of glacial melting rates on the Younger Dryas event and deep-ocean circulation. Nature, 342(6250), 637-642.

Ferrigno, J.G. and W. G. Gould. 1987. Substantial changes in the coastline of Antarctica revealed by satellite imagery. Polar Rec., 23(146), 577-583.

Foldvik, A., T. Gammelsrod and T. Torresen. 1985. Circulation and water masses on the southern Weddell Sea shelf. Antarct. Res. Ser., 43, 5-20.

Fortuin, J. P. F. and J. Oerlemans. 1990. Parameterization of the annual surface temperature and mass balance of Antarctica. Ann. Glaciol., 14, 78-84.

Frolich, R. M. 1992. The surface mass balance of the Antarctic Peninsula ice sheet. In Morris, E. M., ed. The contribution of the Antarctic Peninsula ice to sea level rise. Report of the Commission of European Communities Project EPOC-CT90-0015. Cambridge, British Antarctic Survey, 7-13.

Fujino, K., E. L. Lewis and R.G. Perkin. 1974. The freezing point of seawater at pressures up to 100 bars. 7. Geophys. Res., 79(12), 1792-1797.

Giovinetto, M.B. and C. R. Bentley. 1985. Surface balance in ice drainage systems of Antarctica. Antarct. f. U.S., $20(4), 6-13$.

Giovinetto, M.B., C.R. Bentley and C. Bull. 1989. Choosing between some incompatible regional surface-mass-balance data sets in Antarctica. Antarct. $\mathcal{J}$. U. S., $24(1), 7-13$.

Gloersen, P. and W.J. Campbell. 1991. Recent variations in Arctic and Antarctic sea-ice covers. Nature, 
352(6330), 33-36.

Gordon, A. L. 1983. Comments about the ocean role in the Antarctic glacial ice balance. In Carbon Dioxide Research Conference: Carbon Dioxide, Science and Concensus, Berkeley Springs, WV, September 19-23, 1982. Proceedings. Washington, DC, Oak Ridge Associated Universities, $4.75-4.86$

Gornitz, V., S. Lebedeff and J. Hansen. 1982. Global sea level trend in the past century. Science, 215(4540), 1611-1614.

Gow, A.J. and S. Epstein. 1972. On the use of stable isotopes to trace the origins of ice in a floating ice tongue. 7. Geophys. Res., 77(33), 6552-6557.

Graf, W., O. Reinwarth, H. Oerter and M. Dyurgerov. 1990. Isotopic and stratigraphical interpretation of a $16 \mathrm{~m}$ firn core nearby Druzhnaya I. In Miller, H., ed. Filchner Ronne Ice Shelf Programme. Report No.4. Bremerhaven, Alfred Wegener Institute, 46-49.

Hansen, J. and 6 others. 1988. Global climate changes as forecast by Goddard Institute for Space Studies threedimensional model. 7. Geophys. Res., 93(D8), 93419364.

Hellmer, H.H. and S.S. Jacobs. In press. Ocean interaction with the base of Amery Ice Shelf, Antarctica. 7. Geophys. Res.

Hellmer, H. H. and D.J. Olbers. 1989. A two-dimensional model for the thermohaline circulation under an ice shelf. Antarct. Sci., 1(4), 325-336.

Hellmer, H. H. and D.J. Olbers. 1991. On the thermohaline circulation beneath the Filchner-Ronne ice shelves. Antarct. Sci., 3(4), 433-442.

Hughes, T. 1973. Is the West Antarctic ice sheet disintegrating? 7. Geophys. Res., 78(33), 7884-7910.

Jacka, T.H. 1990. Antarctic and Southern Ocean sea-ice and climate trends. Ann. Glaciol., 14, 127-130.

Jacobs, S. S. 1985. Oceanographic evidence for land ice/ ocean interactions in the Southern Ocean. In Polar Research Board, ed. Glaciers, Ice Sheets, and Sea Level: Effect of a $\mathrm{CO}_{2}$-induced Climatic Change. Report of a Workshop held in Seattle, Washington, September 13-15, 1984. Washington, DC,

National Academy Press, 116-128.

Jacobs, S.S. 1991. Sea-level response to ice sheet evolution: an ocean perspective. In Bindschadler, R.A., ed. West Antarctic Ice Sheet Initiative. Volume 2: discipline reviews. Proceedings of a Workshop. . . . Goddard Space Flight Center, Greenbelt, Maryland, October 16-18, 1990. Washington, DC, National Aeronautics and Space Administration, 23-47. (NASA Conference Publication 3115.)

Jacobs S. S. and D. Barnett. 1987. On the draughts of some large Antarctic icebergs. Iceberg Res., 14, 3-13.

Jacobs, S. S. and J. C. Comiso. 1989. Sea ice and oceanic processes on the Ross Sea continental shelf. F. Geophys. Res., 94(C12), 18,195-18,211.

Jacobs, S. S., A. L. Gordon and J. L. Ardai, Jr. 1979. Circulation and melting beneath the Ross Ice Shelf. Science, 203(4379), 439-443.

Jacobs, S. S., R. G. Fairbanks and Y. Horibe. 1985. Origin and evolution of water masses near the Antarctic continental margin: evidence from $\mathrm{H}_{2}{ }^{18} \mathrm{O}$ / $\mathrm{H}_{2}{ }^{16} \mathrm{O}$ ratios in seawater. Antarct. Res. Ser., 43, 59-85.

Jacobs, S. S., D. R. MacAyeal and J. L. Ardai, Jr. 1986.
The recent advance of the Ross Ice Shelf, Antarctica. 7. Glaciol., 32(112), 464-474.

Jenkins, A. 1991. A one-dimensional model of ice shelfocean interaction. F. Geophys. Res., 96(C11), 20,67120,677 .

Jenkins, A. and C. S. M. Doake. 1991. Ice-ocean interaction on Ronne Ice Shelf, Antarctica. 7. Geophys. Res., 96(C1), 791-813.

Jones, P. D. 1990. Antarctic temperatures over the present century - a study of the early expedition record. F. Climate, 3(11), 1193-1203.

Kameda, T,, M. Nakawo, S. Mae, O. Watanabe and R. Naruse. 1990. Thinning of the ice sheet estimated from total gas content of ice cores in Mizuho Plateau, East Antarctica. Ann. Glaciol., 14, 131-135.

Keys, H.J.R., S. S. Jacobs and D. Barnett. 1990. The calving and drift of iceberg B-9 in the Ross Sea, Antarctica. Antarct. Sci., 2(3), 243-257.

Kipfstuhl, J. 1991. Zur Entstehung von Unterwassereis und das Wachstum und die Energiebilanz des Meereises in der Atka Bucht, Antarktis. Ber. Polarforsch. 85 .

Korotkov, A.I. and A. A. Romanov. 1990. Dynamics of ice conditions in the coastal zone of Antarctica. Polar Geogr. Geol., 14(4), 261-270.

Kotlyakov, V. M., K. S. Losev and I. A. Loseva. 1978. The ice budget of Antarctica. Polar Geogr. Geol., 2(4), 251-262.

Lange, M. A. and H. Kohnen. 1985. Ice front fluctuations in the eastern and southern Weddell Sea. Ann. Glaciol., 6, 187-191.

Lewis, E. L. and R. G. Perkin. 1986. Ice pumps and their rates. F. Geophys. Res., 91(C10), 11,756-11,762.

Lingle, C.S., D. H. Schilling, J. L. Fastook, W.S.B. Paterson and T.J. Brown. 1991. A flow band model of the Ross Ice Shelf, Antarctica: response to $\mathrm{CO}_{2}$ induced climatic warming. 7. Geophys. Res., 96(B4), 6849-6872.

Lorius, C., G. Raisbeck, J. Jouzel and D. Reynaud. 1989. Long-term environmental records from Antarctic ice cores. In Oeschger, H. O. and C. C. Langway, Jr, eds. The environmental record in glaciers and ice sheets. Chichester, etc., John Wiley and Sons, 343-361.

Losev, K. S. 1963. Calculations of the mass balance of the Antarctic ice cap. Sov. Antarct. Exped. Inf. Bull., 5(1), 60-63.

Losev, K. S. 1973. Estimation of run-off from Antarctic and Greenland ice sheets. International Association of Scientific Hydrology Publication 95 (Symposium at Cambridge $1969-$ Hydrology of Glaciers), 253-254.

MacAyeal, D. R. 1984a. Potential effect of $\mathrm{CO}_{2}$ warming on sub-ice-shelf circulation and basal melting. In Environment of $W$. Antarctica: Potential $\mathrm{CO}_{2}$-induced Changes. Report of a Workshop, July 1983, Washington, DC, 212-221.

MacAyeal, D. R. 1984b. Thermohaline circulation below the Ross Ice Shelf: a consequence of tidally induced vertical mixing and basal melting. F. Geophys. Res., 89(C1), 597-606.

MacAyeal, D. R. 1985. Evolution of tidally triggered meltwater plumes below ice shelves. Antarct. Res. Ser., 43, 133-143.

MacDonald, T. R., J. G. Ferrigno, R. S. Williams, Jr and 
B. K. Lucchitta. 1989. Velocities of Antarctic outlet glaciers determined from sequential Landsat images. Antarct. F. U. S., 24(5), 105-107.

McIntyre, N.F. and W. Cudlip. 1987. Observation of a giant Antarctic tabular iceberg by satellite radar altimetry. Polar Rec., 23(145), 458-462.

Markov, K. K., V. I. Bardin, V. L. Lebedev, A. I. Orlov and I. A. Suyetova. 1970. The geography of Antarctica. Jerusalem, Israel Program for Scientific Translations.

Meier, M.F. 1983. Snow and ice in a changing hydrological world. Hydrol. Sci. 7., 28(1), 3-22.

Meier, M.F. 1984. Contribution of small glaciers to global sea level. Science, 226(4681), 1418-1421.

Meier, M.F. 1990. Reduced rise in sea level. Nature, 343(6254), 115-116.

Morgan, V. I. 1972. Oxygen isotope evidence for bottom freezing on the Amery Ice Shelf. Nature, 238(5364), 393-394.

Morgan, V. I. and W.F. Budd. 1978. The distribution, movement and melt rates of Antarctic icebergs. In Husseiny, A. A., ed. Iceberg utilization: proceedings of the First International Conference and Workshops on Iceberg Utilization . . . held at Iowa State University, Ames, Iowa, October 2-6 1977. New York, Pergamon Press, 220-228.

Morgan, V.I., I. D. Goodwin, D. M. Etheridge and C.W. Wookey. 1991. Evidence from Antarctic ice cores for recent increases in snow accumulation. Nature, 354(6348), 58-60.

Navy-NOAA Joint Ice Center. 1973-90. Antarctic ice charts. Suitland, MD, Naval Polar Oceanography Center.

Neal, C.S. 1979. The dynamics of the Ross Ice Shelf revealed by radio echo-sounding. 7. Glaciol., 24(90), 295-307.

Neshyba, S. and E. G. Josberger. 1980. On the estimation of Antarctic iceberg melt rate. 7. Phys. Oceanogr., 10(10), 1681-1685.

Nicholls, K. W., K. Makinson and A. V. Robinson. 1991. Ocean circulation beneath the Ronne Ice Shelf. Nature, 354(6350), 221-223.

Oerter, H. and 6 others. 1990. Glaciological work at Filchner-Ronne ice shelves during the 1989/1990 field season. In Miller, H., ed. Filchner-Ronne Ice Shelf Programme. Report No. 4. Bremerhaven, Alfred Wegener Institute, 98-103.

Orheim, O. 1985. Iceberg discharge and the mass balance of Antarctica. In Polar Research Board, ed. Glaciers, Ice Sheets, and Sea Level: Effect of a $\mathrm{CO}_{2}$-induced Climatic Change. Report of a Workshop held in Seattle, Washington, September 13-15, 1984. Washington, DC, National Academy Press, 210-215.

Orheim, O. 1990. Extracting climatic information from observations of icebergs in the Southern Ocean. (Abstract.) Ann. Glaciol., 14, 352.

Partington, K. C., W. Cudlip, and C. G. Rapley. 1991. An assessment of the capability of the satellite radar altimeter for measuring ice sheet topographic change. Int. 7. Remote Sensing, 12(3), 585-609.

Payne, A.J., D. E. Sugden and C. M. Clapperton. 1989. Modeling the growth and decay of the Antarctic Peninsula ice sheet. Quat. Res., 31(2), 119-134.

Peel, D. A. and R. Mulvaney. 1988. Air temperature and snow accumulation in the Antarctic Peninsula during the past 50 years. (Abstract.) Ann. Glaciol., 11, 207.

Peltier, W. R. and A. M. Tushingham. 1991. Influence of glacial isostatic adjustment on tide gauge measurements of secular sea level change. 7. Geophys. Res., 96(B4), 6779-6796.

Pillsbury, R.D. and S.S. Jacobs. 1985. Preliminary observations from long-term current meter moorings near the Ross Ice Shelf, Antarctica. Antarct. Res. Ser., 43, 87-107.

Polar Research Board, ed. 1985. Glaciers, Ice Sheets, and Sea Level: Effect of a $\mathrm{CO}_{2}$-induced Climatic Change. Report of a Workshop, held in Seattle, Washington, September 13-15, 1984. Washington, DC, National Academy Press.

Potter, J. R. and J. G. Paren. 1985. Interaction between ice shelf and ocean in George VI Sound, Antarctica. Antarct. Res. Ser., 43, 35-58.

Pourchet, M., F. Pinglot and C. Lorius. 1983. Some meteorological applications of radioactive fallout measurements in Antarctic snows. 7. Geophys. Res., 88(C10), 6013-6020.

Radok, U., D. Jenssen and B. J. McInnes. 1987. Antarctic surges - a clear and present danger? In Brown, T.J. and 8 others. On the surging potential of polar ice streams. Washington, DC, U.S. Department of Energy. (Report ER/60197-H1.) [Separate volume.]

Reeh, N. 1985. Greenland ice sheet mass balance and sealevel change. In Polar Research Board, ed. Glaciers, Ice Sheets, and Sea Level: Effect of a $\mathrm{CO}_{2}$-induced Climatic Change. Report of a Workshop held in Seattle, Washington, September 13-15, 1984. Washington, DC, National Academy Press, 155-171.

Robin, G. de Q. 1979. Formation, flow and disintegration of ice shelves. 7. Glaciol., 24(90), 259-271.

Robin, G. de Q. 1983. Coastal sites, Antarctica. In Robin, G. deQ., ed.The climatic record in polar ice sheets. Cambridge, Cambridge University Press, 118-122.

Robin, G. de Q. 1987. Changing the sea level. In Bolin, B., B. R. Doos, J. Jager and R.A. Warrick, eds. The greenhouse effect, climatic change and ecosystems. Chichester, etc., John Wiley and Sons, 323-359.

Savatyugin, L. and R. Vaykmaye. 1990. On the genesis of the Shackleton Ice Shelf according to oxygen-isotope data. Geodätische und Geophysikalische Veröffentlichungen, Reihe 1, 16, 291-298.

Scheduikat, M. and D.J. Olbers. 1990. A one-dimensional mixed layer model beneath the Ross Ice Shelf with tidally induced vertical mixing. Antarct. Sci., 2(1), 29-42.

Schlesinger, M. E. 1985. A numerical simulation of $\mathrm{CO}_{2}$ induced transient climate change with a coupled atmosphere-ocean general circulation model. In Polar Research Board, ed. Glaciers, Ice Sheets, and Sea Level: Effect of a $\mathrm{CO}_{2}$-induced Climatic Change. Report of a Workshop held in Seattle, Washington, September 13-15, 1984. Washington, DC, National Academy Press, 267-274.

Schlosser, P., R. Bayer, A. Foldvik, T. Gammelsrod, G. Rohardt and K. O. Münnich. 1990. Oxygen 18 and helium as tracers of ice shelf water and water/ice interaction in the Weddell Sea. 7. Geophys. Res., 95(C3), 3253-3263.

Shabtaie, S. and C. R. Bentley. 1987. West Antarctic ice streams draining into the Ross Ice Shelf: configuration and mass balance. 7. Geophys. Res., 92(B2), 1311-1336. 
Smith, N.R., Dong Zhaoqian, K. R. Kerry and S. Wright. 1984. Water masses and circulation in the region of Prydz Bay, Antarctica. Deep-Sea Res., 31(9A), 1121-1147.

Souchez, R. and 8 others. 1991. Ice composition evidence of marine ice transfer along the bottom of a small Antarctic ice shelf. Geophys. Res. Lett., 18, 849-852.

Stouffer, R.J., S. Manabe and K. Bryan. 1989. Interhemispheric asymmetry in climate response to a gradual increase of atmospheric $\mathrm{CO}_{2}$. Nature, 342(6250), 660-662.

Swithinbank, C. 1988. Satellite image atlas of glaciers of the world. Antarctica. U. S. Geol. Surv. Prof. Pap. 1386B.

Swithinbank, C., P. McClain and P. Little. 1977. Drift tracks of Antarctic icebergs. Polar Rec., 18(116), 495501.

Thomas, R.H. 1987. Future sea level rise and its early detection by satellite remote sensing. Prog. Oceanogr., 18, 23-40.

Thomas, R. H. and P. H. Coslett. 1970. Bottom melting of ice shelves and the mass balance of Antarctica. Nature, 228(5266), 47-49.

Thomas, R.H. and D. R. MacAyeal. 1982. Derived characteristics of the Ross Ice Shelf, Antarctica. 7 . Glaciol., 28(100), 397-412.

Thomas, R.H., T.V. Martin and H.J. Zwally. 1983. Mapping ice-sheet margins from radar altimetry data. Ann. Glaciol., 4, 283-288.

Trumbore, S.E., S.S. Jacobs and W. M. Smethie, Jr. 1991. Chlorofluorocarbon evidence for rapid ventilation of the Ross Sea. Deep-Sea Res., 38(7A), 845-870.

Wadhams, P. 1988. Winter observations of iceberg frequencies and sizes in the South Atlantic Ocean. $\mathcal{J}$. Geophys. Res., 93(C4), 3583-3590.

Warrick, R. and J. Oerlemans. 1990. Sea level rise. In Houghton, J., G. Jenkins and J. Ephraums, eds. Climate change: the IPCC Scientific Assessment. Cambridge, Cambridge University Press, 257-281.

Weatherly, J. W., J.E. Walsh and H.J. Zwally. 1991. Antarctic sea ice variations and seasonal air temperature relationships. J. Geophys. Res., 96(C8), 15,11915,130 .
Weeks, W. F. and M. Mellor. 1978. Some elements of iceberg technology. In Husseiny, A. A., ed. Iceberg utilization: proceedings of the First International Conference and Workshops on Iceberg Utilization . . . held at Iowa State University, Ames, Iowa, October 2-6 1977. New York, Pergamon Press, 45-98.

Weiss, R.F., H. G. Östlund and H. Craig. 1979. Geochemical studies of the Weddell Sea. Deep-Sea Res., 26(10A), 1093-1120.

Wexler, H. 1960. Heating and melting of floating ice shelves. 7. Glaciol., 3(27), 626-645.

Wexler, H. 1961. Ice budgets for Antarctica and changes in sea-level. J. Glaciol., 3(29), 867-872.

Whillans, I. M., J. Bolzan and S. Shabtaie. 1987. Velocity of ice streams B and C, Antarctica. 7. Geophys. Res., 92(B9), 8895-8902.

Zakharov, V.G. 1988. Fluctuations in ice shelves and outlet glaciers in Antarctica. Polar Geogr. Geol., 12(4), 297-311.

Zotikov, I. A. 1963. Bottom melting in the central zone of the ice shield on the Antarctic continent and its influence upon the present balance of the ice mass. International Association of Scientific Hydrology Bulletin, $8(1), 36-44$.

Zotikov, I. A. 1986. The thermophysics of glaciers. Dordrecht, D. Reidel Publishing Co.

Zotikov, I. A., V.S. Zagorodnov and J. V. Raikovsky. 1980. Core drilling through the Ross Ice Shelf (Antarctica) confirmed basal freezing. Science, 207(4438), 1463-1465.

Zverev, A. A. 1964. Anomalous sea water temperatures in Olaf Prydz Bay. Sov. Antarct. Exped. Inf. Bull., 1, 269271.

Zwally, H.J. 1989. Growth of the Greenland ice sheet: interpretation. Science, 246(4937), 1589-1591.

Zwally, H.J., S. N. Stephenson, R. A. Bindschadler and R.H. Thomas. 1987. Antarctic ice-shelf boundaries and elevations from satellite radar altimetry. Ann. Glaciol., 9, 229-235.

The accuracy of references in the text and in this list is the responsibility of the authors, to whom queries should be addressed. 